\title{
Consumption of Wild Perennial Medicinal Herbs by Indigenous People of Assam
}

\author{
Swapnali Borah* and Nilakhi Borah
}

College of Community Science, CAU, Tura, Meghalaya, India

*Corresponding author

Keywords

Assamese

community, Ethnic medicine, Wild

herbs consumption pattern, Perennial medicinal plant \& Traditional belief

Article Info

Accepted:

12 December 2020

Available Online:

10 January 2021

\section{A B S T R A C T}

Assam is a state of North East India which is amidst of greenery and varieties of flora and fauna. Since time immemorial the Assamese people consume various green herbs as food as well as medicinal purposes. In this study, Nagaon district which is known as heart of Assam or middle Assam was selected for the purpose. Ten housewives from ten various villages of Nagaon district of Assam were selected purposively who were involved in cooking traditional food particularly. Five herbs namely Stink vine (Vedai Lota in Assamese), Water pennywort (Xoru manimuni in Assamese), Creeping smart weed (Moduxuleng in Assamese), Fish mint (Mosondori in Assamese) and Racaba (Matikaduri in Assamese) also selected for the study which are grown wildly and abundantly throughout Assam particularly during spring season. These wildly grown plants are used traditionally by Assamese community in many recipes for various ailments.

\section{Introduction}

Human race from the very beginning have been depending upon plant and animal kingdom for food and many other purposes. This dependency of human on plant resource is as old as human civilization. With passing on time with experience they could identify different plants and herbs and their action on human health. Almost entire people of the world consume medicinal plants for their inherent medicinal properties and effectiveness (D. K Bhattachrjee and $\mathrm{P} C$ Borah, 2006). In India this practice of using herbs goes back to the days of Vedic era. The Rig Veda mentioned ninety nine, Yajur Veda mentioned eighty eight and Athrva Veda mentioned 28 medicinal plants (Maiti R K et al).

Assam, being in the sub tropical humid climatic region having an elevation between 45 meter and 1960 meters from sea level is a heaven for varieties of flora and fauna. It is in the moist tropical forest region, so naturally 
Assam is a home for evergreen trees, tropical canopy trees, deciduous trees, under story trees including shrubs, herbs, ferns and grasses. People of Assam have been using these plants for various purposes for day to day life for ages. For example bamboos, reeds, theshing grasses for building houses, tree wood for furniture and fire, different edible fruits, vegetables, leaves and herbs for foods. In Assam, most of the edible plants and wild vegetation grow in the kitchen garden of Assamese household or around their homestead (B. Patiri and A. Borah, 2007). Herbs that grow in Assam and North East Region of India have full of nutritional and medicinal values.

There are many herbs grow in Assam wildly which are traditionally consumed by Assamese people in their day to day life such as Stink vine (Vedai Lota in Assamese), Water pennywort (Xoru manimuni in Assamese), Creeping smart weed (Moduxuleng in Assamese), Fish mint (Mosondori in Assamese), Curry leaf (Noroxingha in Assamese), Creep wood sorrel (Tengechi in Assamese), Flame flower (Pirali paleng in Assamese), Verdologo (Malbhog xak in Assamese), Patchouli (Xukloti in Assamese), Wild pepper (Bon jaluk), Mint (Podina in Assamese), Hog weed (Ponounua), Chick weed (Morolia in Assam ese), Racaba (Matikaduri in Assamese), Water spinach (Kolmou in Assamese), Leucus plant (Durun bon in Assamese), Indian Pivet (Posotia in Assamese), Lamb squarter (Jhilmil in Assamese), Rosselle (Tengamora in Assamese), Brahmi (Brahmi in Assamese too) etc. Apart from these herbs, there are many more edible herbs growing in these region. In the time of Bohag Bihu, a spring festival of Assam celebrated in the month of April, there is a tradition of having a cuisine made of hundred and one different varieties of herbs grown wildly during onset of early monsoon in Assam. Though there are different varieties of edible herbs found in this area, certain herbs are more popular and consumed more frequently than the rest.

Trans Himalayan indigenous people including people Assam have some distinctive food habits. Most of the people here eat vegetarian as well as non vegetarian food. They eat boiled, alkaline and sour preparation, bitter is also given a prime place in Assamese food menu. Curry is also an indispensable item with rice. In the hot and humid climate of Assam traditionally food is used in such a way that, it cools the stomach all the time. Therefore food preparations are always milder with less spice. Often a herbal food preparation is consumed with lunch or dinner. These herbal preparations are cooked sometime as vegetarian and sometime with fish but rarely with meat. (Arani Saikia, 2013)

\section{Materials and Methods}

For the purpose of the study ten housewives who were involved in traditional cooking practices were selected purposively from ten villages of Nagaon district of Assam, India and conducted case studies by following interview method. Nagaon district is situated on the middle of the state of Assam, India. The geographic coordinates of the district head quarter which is also Nagaon is 26 degree North latitude and 92 degree east longitude. Its elevation is 52 meters from the sea level. The topography is filled with hills, plain alluvial river valleys and lots of water bodies including ponds, streams, rivers, wetlands etc. Nagaon receives an average annual rainfall of around $2036 \mathrm{~mm}$. It is placed in Agro Climatic Zone of Eastern Himalaya Region as per Planning Commission and Central Brahmaputra Valley Zone as per NARP (India). Due to its natural geographical location Nagaon is very rich in natural resources. Entire topography is almost green with natural vegetations which include 
different trees, shrubs, herbs and grasses. Among various edible herbs, five most popular and easily available herbs i.e. 1) Stink Vine or Skunk Vine (English)/ Bhebeli Lota or Bhedai Lota (Assamese), 2) Lawn Marsh Pennywort or Water Pennywort (English)/ Soru Manimuni (Assamese), 3) Creeping smartweed, Chinese knotweed (English), Modhuxuleng (Assamese), 4) Fish mint, (English), Masundori (Assamese), and 5) Racaba (English), Matikaduri (Assamese) were selected for this study.

\section{Results and Discussion}

Stink Vine or Skunk Vine (English)/ Bhebeli Lota or Bhedai Lota (Assamese):

The scientific name of this herb is known as Paederia foetida which is a very popular and widely consumed herb by the ethnic people of Assam. Belonging to the Rubiaceae family of plant kingdom, it is a climber found up to the elevation of nearly 1800 meter from the sea level in Bihar, Orissa, Bengal and Assam (Nadkarni 1982). It grows up to 6-7 meter long and climb on other trees for support. It is also available in some other parts of North East India like Meghalaya, Arunachal Pradesh, Nagaland, Manipur, Mizoram and Tripura. The unique character of this plant is the stink smell it produces when the leaf or stem is crushed.

Traditionally the people of Assam and North East India consume this plant in various forms according to their need and ailment. For medicinal purpose decoction of the whole plant or leaf juice is prepared. Tender leaves are used to prepare different cuisine for food. Stink vine gives various therapeutic effects mainly gastrointestinal tract disorders including ulcer. Other therapeutic properties are hepatoprotective, anti inflammatory, antitussive, anti arthritics, antioxidant, analgesic, and others. (Silpi Chanda et al.,
2013). In Nagaon district of Assam also Stink vine is consumed for different purposes, in post child delivery care of women it is extensively used as food. For this purpose Stink vine paste is prepared from tender leaves and cooked with some indigenous fish species like Climbing Perch or Kawai Fish in Assamese (Anabus testudineus) Cat Fish or Magur Fish in Assamese (Clarius butrachus), Snakehead fish or Sol Fish in Assamese (Channa striatus) or lentil balls and spices like black pepper etc. and served with steamed rice (Table.1) When there is gastro intestinal problem like loss of appetite and indigestion Stink vine tender leaves and Garlic chutney is consumed to increase appetite and digestion. More over different preparations of Stink vines are consumed to boost general immunity. Stink vine deep fried balls made with rice flour or lentil flour is a popular preparation in Nagaon, Assam and throughout Assam. Tribes of Tripura prepare Berma bauti or Gudak using dry fish and leaves of Stink vine (Das 1997).

\section{Lawn Marsh Pennywort or Water Pennywort (English)/ Soru Manimuni (Assamese)}

The Scientific Name of this Lawn Marsh Pennywort is Hydrocotyle sibthorpioides, which is a small dicotyledonous plant found in the Southeast Asian countries. It is traditionally falls in the family of Apiaceae but recently suggested to place in Araliaceae (Chandler 2004) of the plant kingdom. Size of the leaves are .5 to $2 \mathrm{~cm}$ wide and shape is round or kidney shaped. Edges of the leaves are scalloped. Color of flowers is light yellow with some purple spots. Stems grow up to 8$10 \mathrm{~cm}$ long. (B. Patiri, A. Borah 2007)

Lawn marsh pennywort believed to have very good medicinal properties, it contains different minerals, iron and vitamin $\mathrm{C}$. Traditionally in Assamese society this herb is 
used for flu, fever cough, gastrointestinal disorder etc. Young leaves and shoots are cooked as vegetable. Normally a paste is prepared from tender leaves and stems then cooked with fishes like Climbing Perch or Kawai Fish in Assamese (Anabus testudineus), Spotted Snakehead or Goroi Fish in Assamese (Channa punctata) and garlic, black pepper etc., this curry can be prepared without fish too. Chutney can also be prepared out of Lawn marsh pennywort. Some people consume the raw juice too. Paste of raw Lawn marsh pennywort leaves are topically used in healing wounds (Table.1).

\section{Creeping smartweed, Chinese knotweed (English), Modhuxuleng (Assamese)}

This is perennial creeper herb that falls in Polygonaceae family of plant kingdom and scientific name is Polygonum microcephalum is. It grows normally in damp or shady places throughout China, East Asia particularly Nepal and Assam (Manandhar N.P. 2002). The plant grows up to $.5 \mathrm{~m}$ long, size of the leaf is $5-10 \mathrm{~cm}$ long with a shape of oval blade and tip is pointed. Stems are reddish green in color and are soft.

Traditionally people of Nagaon district of Assam use this herb for medicinal purpose as well as a tasty leafy vegetable. It has got a sour taste. It is believed to be very good for gastro intestinal ailments like dysentery. It is said to be good for lung ailments like bronchitis, cough also (Table.1).

Assamese people consume this herb in many ways. Creeping smartweed leaves and fish curry is very popular in this region. Any type of fish is used for this cuisine, normally only salt and turmeric powder is used without any other spice. Even without fish this curry tastes good, can be cooked using potato slices or grinded lentil balls. Sweet and sour chutney is also prepared from its leaves with salt, sugar or jaggery. It is also cooked with lentil soups which give a unique flavor and taste.

\section{Fish mint, (English), Masundori (Assamese)}

Scientific Name of this plant is Houttuynia cordata which is a perennial ground cover plant that grows on the damp and shady soil. It falls under the Family Saururaceae of plant kingdom. Stems are soft, grow up to .6 to 1 meter and spread up to 1 meter. Leaves are alternate and heart shaped, 4-9 cm long and 3$8 \mathrm{~cm}$ broad. (Hedrik U.P. 1972). It is a native plant of China, Japan, Korea and South East Asia, (F.Chittendon 1956) found up to an altitude of 2500 meters from the sea level.

Fish mint is said to be good source of Vitamin A Carotene and Calcium, it also contains protein, fat, minerals, iron and fiber. People of Assam are using this particular herb as medicine purpose for ages. They believe that it works tremendously against gastrointestinal disorder like Dysentery and indigestion (Table.1). Normally it is wrapped in banana leaves and put it over burning wood charcoal to cook and then mixed with salt and raw mustard oil. The pungent smell of raw mustard oil gives a typical flavor which is liked by Assamese people. It is sometime cooked with Taro (Colocasia esculenta) which is also very popular in Assam. Some people eat fish mint raw as salad dressing. It is also found that the Garo tribe of Meghalaya consumes this herb as chutney with dry fish.

\section{Racaba (English), Matikaduri (Assamese)}

Scientific Name of this Racaba is Alternanthera sessilis which is a perennial herb under the family of Amaranthaceae of plant kingdom. It has prostrate stems and often roots come out from the nodes. Leaves are $1-1.5 \mathrm{~cm}$ long and $.3-3 \mathrm{~cm}$ wide, elliptical in size. Flowers are tiny and white. It is 
available throughout the world in tropical region.

In many places in South East Asia leaves and shoots of Racaba is consumed as vegetables (Grubben, G.J.H. \& Detton, O.A. 2004). It has diuretic, cooling, tonic and Laxative properties. It is used for dysuria and hemorrhoids (Tanaka, Yoshitaka, Van ke and Nguyen 2007). And also believed to be good for eyes. In Nagaon district of Assam traditionally Racaba is believed to be good for lactating mother. It is used for toning blood and muscles too. It is believe that Racaba juice mixed with lemon juice can cure dysentery. Mixer of Racaba with yellow wood sorrel and water pennywort is believed to be good for heart. In Assam this herb is consumed in various ways. It can be consumed just boiled with water in salt. Curry can also be prepared with fish and tomato which is very tasty and popular throughout Assam. Even without fish, Racaba curry is prepared with sliced potato which is also popular among Assamese people Table.1).

Table.1 Indigenous wild edible herbs with their botanical name, family, vernacular name, English name, edible parts and medicinal use

\begin{tabular}{|c|c|c|c|c|c|c|}
\hline $\begin{array}{l}\text { Sl } \\
\text { No. }\end{array}$ & Botanical name & Family & $\begin{array}{l}\text { Vernacular name } \\
\text { (Assamese) }\end{array}$ & $\begin{array}{c}\text { English } \\
\text { name }\end{array}$ & $\begin{array}{l}\text { Edible } \\
\text { parts }\end{array}$ & Medicinal use \\
\hline 1. & Paederia foetida & Rubiaceae & $\begin{array}{l}\text { Bhebeli Lota or } \\
\text { Bhedai Lota }\end{array}$ & $\begin{array}{l}\text { Stink vine } \\
\text { or } \\
\text { Skunk } \\
\text { vine }\end{array}$ & $\begin{array}{l}\text { Leaves } \\
\text { and } \\
\text { tender } \\
\text { stems }\end{array}$ & $\begin{array}{l}\text { Post child delivery } \\
\text { care of women, } \\
\text { Gastro-intestinal } \\
\text { ailments, Musculo- } \\
\text { skeletal pain etc. }\end{array}$ \\
\hline 2. & $\begin{array}{l}\text { Hydrocotyle } \\
\text { sibthorpioides }\end{array}$ & Apiaceae & Soru Manimuni & $\begin{array}{l}\text { Lawn } \\
\text { marsh } \\
\text { pennywort } \\
\text { or water } \\
\text { pennywort }\end{array}$ & $\begin{array}{l}\text { Leaves } \\
\text { and } \\
\text { tender } \\
\text { stems }\end{array}$ & $\begin{array}{l}\text { Flu, Cough, fever, } \\
\text { gastro-intestinal } \\
\text { disorder, healing } \\
\text { wound etc. }\end{array}$ \\
\hline 3. & $\begin{array}{l}\text { Polygonum } \\
\text { microcephalum }\end{array}$ & Polygonanceae & Modhuxuleng & $\begin{array}{l}\text { Creeping } \\
\text { smartweed } \\
\text { or Chinese } \\
\text { knotweed }\end{array}$ & Leaves & $\begin{array}{l}\text { Dysentery, lung } \\
\text { ailments like cough } \\
\text { Bronchitis etc. }\end{array}$ \\
\hline 4. & $\begin{array}{l}\text { Houttuynia } \\
\text { cordata }\end{array}$ & Saururaceae & Masondori & $\begin{array}{l}\text { Fish mint } \\
\text { or Heart } \\
\text { leaf }\end{array}$ & Leaves & $\begin{array}{l}\text { Gastro-intestinal } \\
\text { disorders like } \\
\text { Dysentery, } \\
\text { indigestion etc. }\end{array}$ \\
\hline 5. & $\begin{array}{l}\text { Alternanthera } \\
\text { sessilis }\end{array}$ & Amaranthaceae & Matikaduri & Racaba & $\begin{array}{l}\text { Leaves } \\
\text { and } \\
\text { tender } \\
\text { stems }\end{array}$ & 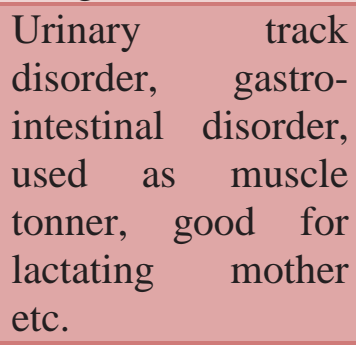 \\
\hline
\end{tabular}


Table.2 Frequency of wild perennial medicinal herbs consumption pattern of Assamese Family $(\mathrm{N}=100)$

\begin{tabular}{|c|c|c|c|c|c|c|c|}
\hline $\begin{array}{l}\text { Sl } \\
. \mathrm{N} \\
\mathbf{0}\end{array}$ & $\begin{array}{l}\text { Scientific } \\
\text { Name }\end{array}$ & $\begin{array}{l}\text { Vernacular } \\
\text { Name } \\
\text { (Assamese) }\end{array}$ & Weekly & $\begin{array}{l}\text { Fortnightl } \\
\text { y }\end{array}$ & Monthly & $\begin{array}{l}\text { Once in } \\
\text { two } \\
\text { month }\end{array}$ & $\begin{array}{l}\text { Once in } \\
\text { six } \\
\text { month }\end{array}$ \\
\hline 1 & $\begin{array}{l}\text { Paederia } \\
\text { foetida }\end{array}$ & $\begin{array}{l}\text { Bhebeli Lota } \\
\text { or Bhedai } \\
\text { Lota }\end{array}$ & 16 & 22 & 43 & 14 & 5 \\
\hline 2 & $\begin{array}{l}\text { Hydrocotyle } \\
\text { sibthorpioides }\end{array}$ & $\begin{array}{l}\text { Soru } \\
\text { Manimuni }\end{array}$ & - & - & 26 & 43 & 31 \\
\hline 3 & $\begin{array}{l}\text { Polygonum } \\
\text { microcephalu } \\
m\end{array}$ & $\begin{array}{l}\text { Modhuxulen } \\
g\end{array}$ & - & 14 & 41 & 25 & 20 \\
\hline 4 & $\begin{array}{l}\text { Houttuynia } \\
\text { cordata }\end{array}$ & Masondori & 20 & 23 & 38 & 17 & 2 \\
\hline 5 & $\begin{array}{l}\text { Alternanthera } \\
\text { sessilis }\end{array}$ & Matikaduri & - & - & - & 35 & 65 \\
\hline
\end{tabular}

Fig.1
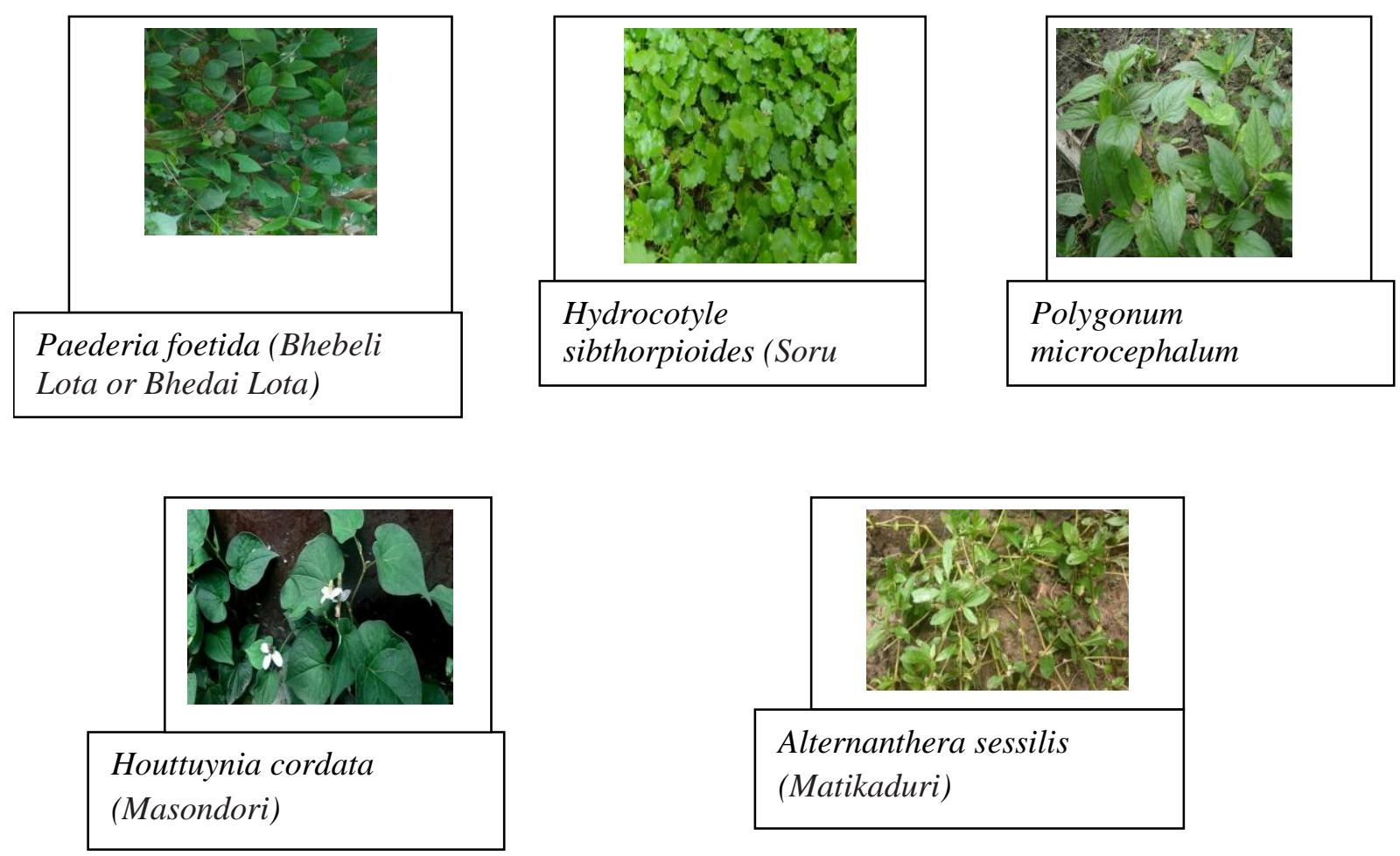


\section{Consumption pattern of herbs}

Assamese cuisine is incomplete without herbal medicinal plant grown widely in Assam. Apart from using as medicine for some particular ailments, they consume these herbs in their meals too. In this study it was found that most $(43 \%)$ of the Assamese rural families were consumed Paederia foetida monthly which is followed by 22 percent families fortnightly. Hydrocotyle sibthorpioides was consumed mostly (43\%) on once in two months which is followed by once in six months (31\%). Again both Polygonum microcephalum and Houttuynia cordata were consumed mostly (41\% and 38 $\%$ respectively) once in a month by Assamese families of rural areas of Nagaon district of Assam. But 65 percent Assamese families consumed Alternanthera sessilis once in six months and 35 percent once in two months in their meal. In further analysis, it was found that Assamese people have a habit of consuming these herbs in their lunch only. (Table 2)

In conclusion, the natural resources have a big impact on the entire population living in a particular region in every aspects of life including tradition, culture, health, economy etc. People of Assam have been traditionally using these natural edible herbs for centuries. Whoever has been using these herbs regularly are getting benefits in different ways. As for example first and foremost is health benefit. Secondly this practice of consuming natural herbs leads to decrease in dependency on vegetables which we have to buy from the market spending money. And this way we are getting an economic benefit. And thirdly this practice indirectly decreases dependency on medicines too, as consumption of different natural herbs boost up the immunity so less chance of falling ill. But nowadays with the development of new urban areas and adoption of modern lifestyles many people of this region started forgetting this tradition. And with time many herbs and their uses are gone out of our mind. Therefore it is very much essential to give importance on those herbs. New scientific research should be carried out. The knowledge of these herbs should go to each and every individuals of this region so that they can get the benefit out of these naturally growing herbs and lead a healthy and prosperous life.

\section{References}

Bhattacharjya D K \& Borah P C Medicinal weeds of crop fields and role of women in rural health and hygiene in Nalbari district, Assam. Indian journal of Traditional Knowledge. 7(3) (2006) 501-504. https://pdfs.semanticscholar. org/1ea7/f59b8aee15f6daff26ec3d28c0 8f52bd85af.pdf

Chandler G T, Plunkett G M (2004-02-01). Evolution in Apiales: nuclear and chloroplast markers together in (almost) perfect harmony. Botanical Journal of the Linnean Society. 144 (2)(2004). http://europepmc.org/ article/AGR/IND43622559

Chittendon. RHS, Dictionary of Plants plus Supplement. 1956 Oxford University Press.

Das P. Wild tribal plants of Tripura tribes. Published by Tripura Tribal Cultural Research Institute \& Museum, Government of Tripura,1997.

Grubben, G J H. \& Denton, O A Plant Resources of Tropical Africa 2. Vegetables. PROTA Foundation, Wageningen; Backhuys, Leiden; CTA, Wageningen. (2004). https://www. scirp.org/ (S(351jmbntvnsjt1aadkposzje))/referen ce/ReferencesPapers.aspx?ReferenceID $=1138411$

Hedrick U P, Sturtevant's Edible Plants of the World. Dover Publications (1972). 
https://www.researchgate.net/publication/257 717835_Paederia_foetida_a_promisin g_ethno-medicinal_tribal_plant_of_ northeastern_India

Maiti R K, Petriz-Olvera R A, SanchezArreola E, Osvaldo-Ramirez E \& Singh V P. Medicinal plant species selected and confirmed for their efficiency to cure different diseases, Crop Research 25(3) (2003)

550. http://cropresearch.org/volume-25number-3-may-2003/

Manandhar N P, Plants and People of Nepal, Timber Press. Oregon. (2002). https://ethnobiology.org/sites/default/fil es/pdfs/JoE/23-2/Sacherer2003.pdf

Nadkarni KM, The Indian Materia Medica. Bombay: Popular Prakashan1982. https://trove.nla.gov.au/work/18643838 ?q\&versionId=21887031

Patiri, B., A. Borah, Wild edible plants of
Assam, published by the Director Forest Communication, Forest, Assam, (2007). http://103.8.249.31/ assamforest/ publication/wildEdible plantsAssam.pdf Saikia A, Food-Habits in Pre-Colonial Assam, International Journal of Humanities and Social Science Invention 2(6) (2013) 01-05. http://www.ijhssi.org/ papers/v2(6)/Version-2/A02620105 .pdf

Silpi Chanda, Indira P Sarethy, Biplab De \& Kuldeep Singh Paederia foetida - a promising ethno-medicinal tribal plant of northeastern India. Journal of Forestry Research 24(4) (2013) 801-808

Tanaka, Yoshitaka, Van Ke, Nguyen Edible Wild Plants of Vietnam: The Bountiful Garden. Thailand: Orchid Press. (2007). p. 21.

\section{How to cite this article:}

Swapnali Borah and Nilakhi Borah. 2021. Consumption of Wild Perennial Medicinal Herbs by Indigenous People of Assam. Int.J.Curr.Microbiol.App.Sci. 10(01): 1952-1959. doi: https://doi.org/10.20546/ijcmas.2021.1001.227 